\title{
The Relationship between Demographic Status and Comorbid Disease with the Risk of Chronic Kidney Disease in the Cut Meutia Hospital, Aceh Utara Regency
}

\author{
Anita Marlina', Said Usman ${ }^{2}$, Yusni $^{3}$, Maimun Syukri' ${ }^{4}$, Hanifa Yusuf ${ }^{5}$ \\ 1,2,3,4,5 Magister Program in Public Health, Faculty of Medicine, Universitas Syiah Kuala, Banda Aceh, Indonesia \\ anitaamalia34@gmail.com,saidusman@unsyiah.ac.id,yusni@unsyiah.ac.id,maimun_62@yahoo.com, \\ hans_yusuf1104@yahoo.com
}

\begin{abstract}
This research aims to analyze the risk factors associated of Chronic Kidney Disease (CKD). This research was conducted in Rumah Sakit Umum Cut Meutia (RSUCM) North Aceh. Based on the Law of the Republic of Indonesia No. 39 Year 2009 regarding the prevention and control of disease not contagious is an attempt to improve the health of the community through activities promotive and preventive. This research is a cross sectional analytic research with a retrospective approach, this research is by searching the previous data. The data used in this study are secondary data at Rumah Sakit Umum Cut Meutia (RSUCM), North Aceh Regency in 2019, which aims to analyze risk factors associated with Chronic Kidney Disease (CKD). This research was conducted at Rumah Sakit Umum Cut Meutia (RSUCM), North Aceh District from 8 to 9 June 2020. The population included in this study were all patients with chronic kidney disease who received treatment at the Cut Meutia General Hospital in North Aceh Regency for the period January - December 2019 as many as 640 people.There is a relationship between the status of the demographics on the gender with risk the occurrence of disease chronic kidney where $p$ value 0,452. There is relationship between disease comorbid in hypertension with the risk of the occurrence of disease chronic kidney where p value by 0,000. The relationship between disease comorbid in diabetes risk the occurrence of disease chronic kidney where p value by 0,000.
\end{abstract}

Keywords

chronic kidney disease, risk factors, etiology

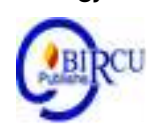

\section{Introduction}

Increasing the case of kidney disease pose an increased health care revolves around two million people. People who have kidney disease chronic require renal replacement therapy such as dialysis or kidney transplantation ranges from $10 \%$ with number of deaths greater (Mullins et al., 2016). Patients with chronic kidney disease most great potential can be treated by starting the appropriate treatment as an effort to prevent the development of chronic disease is a disease end-stage kidney (Sharma et al., 2018). Chronic kidney disease divided into five stage of the end of the marked damage of the kidney so that requires renal replacement therapy such as peritoneal dialysis, hemodialysis, and kidney transplant. Therapy made by the community, namely is hemodialysis (Colvy, 2010; Shdaifat, 2012). The problem related to chronic kidney disease due to impaired quality of life and life expectacy at all ages. Disease chronic kidney influenced by age, gender, and disease cardiovascular conditions such as diabetes, infection, and cancer (Haileamlak, 2018; the Nature and Hadibroto, 2007). 
Other risk factors such as age, gender, race, ethnicity, family history, drug use, smoking, as well as the influence of other caused due to socio-economic status and disease degenerative namely hypertension, diabetes mellitus, heart disease, obesity, and uric acid (Kazancioğlu, 2013.; Hwang et al., 2009). The data of province Aceh disease not contagious include hypertension as much as 172.213 cases, diabetes 97.033 cases, stroke 32.200 cases, asthma bronchiale 26.412 case and obesity 23.531 case. Based on the Law of the Republic of Indonesia No. 39 Year 2009 regarding the prevention and control of disease not contagious is an attempt to improve the health of the community through activities promotive and preventive (Department Of Health Of Aceh, 2018).

Rumah Sakit Umum Cut Meutia is a government owned hospital that built in 1961 and 1963. Rumah Sakit Umum Cut Meutia improved classification of B-Type with the Decision of the Minister Health R. I Number: HK.03.05/I/2166/11. RSUCM provide optimum service for the community as well as being home hospital education. The rising cases of kidney disease can be seen based on the increased incidence and pervalensi kidney disease chronic. Data of research was obtained from the medical record shows that the case of chronic kidney disease in 2019 amounted to 640 people (Rumah Sakit Umum Cut Meutia, 2020).

Kidney chronic disease can be recognized early on complications of the disease hypertension and diabetes, so kidney disease can be prevented by getting treatment immediately. Examination of kidney function conducted to determine the decline in renal function. Examination of the blood aims to see the levels of urea, creatinine and the rate of filtration the glomerulus, while examination of urine to see the levels of albumin or protein.

\section{Review of Literatures}

\subsection{Chronic Kidney Disease (CKD)}

Chronic kidney disease is the type of disease that can decrease kidney function which is caused a variety of abnormalities, so that the function excretion, endocrine, metabolic decline and develop into CKD (Anand et al., 2017; Webster et al., 2017; Haileamlak, 2018).

Chronic kidney disease is a disease that occurs due to the decline in renal function or the estimated the rate of filtration glomerular (eGFR) less than $60 \mathrm{ml} / \mathrm{min} / 1.73 \mathrm{mt} 2$, last for 3 months or more (Vaidya and Aeddula, 2020, Damtie et al., 2018; Wouters et al., 2015).

The development of chronic kidney disease due to by diabetes, hypertension, and other disorders. The disease result in damage to the kidneys due to abnormalities in urine sediment and calcium in the blood, seen based on estimates of the rate of filtration glomerular (eLFG), the level of ekresi urine albumin (AER), so that lose the ability to filter the blood and increase the risk of cardiovascular disease (Matovinović, 2009., Fraser and Blakeman, 2016., Damtie et al., 2018) .

\subsection{Etiology}

Wrong one of the main causes of chronic kidney disease occur due to factors the risk of disease cerebrovascular and cardiovascular which can lead to death. Based on the causes of chronic kidney disease are found in diseases as the following:

a. Diabetes mellitus is a metabolic disease with hyperglycemia that occurs due to abnormalities of secretion of the urine that can cause complications in the organs kidney.

b. Glomerulonephritis is inflammation of the glomerular and spread on atubular, intertisial and vascular. 
c. Hypertension is an increase in blood pressure above $>140 / 90 \mathrm{mmHg}$, with causes sodium retention, which occurs due to the increase in systemReninAngiotensin Aldosterone(RAA). The increase vasokontriksi on blood pressure affect the sympathetic nervous system, causing damage kidney.

d. Uropati obstructive is blockage of urine output, which can be one or both of kidneys.

e. Nephritis interstitial chronic is an infection that causes swelling around the nephron

f. Disease kidney polycystic an autosomal dominant is kidney disease due to hereditary factors, as well as the cause other in chronic kidney disease of unknown. (Sharma et al., 2018; Vaidya and Aeddula, 2020).

\subsection{Risk Factors}

a. Age

Age is the risk factors on the incidence of chronic kidney disease due to a decrease in the rate of filtration glomerular (eGFR) lower and albuminuria were higher in old age (Hallan et al., 2012., Haileamlak, 2018) . Age affect other risk factors end-stage renal disease (ESRD) and death in patients referred and not referred, with risk the incidence of ESRD is high compared to the risk of death without ESRD, at the age of $<60$ years. (Nitta et al., 2013).

Increasing age, renal function decreased range $10 \mathrm{ml} / \mathrm{min} / 1.73 \mathrm{~m} 2$, with the value of Glomelural Filtration Rate (GFR) $60-89 \mathrm{ml} / \mathrm{min} / 1.73 \mathrm{~m} 2$ (Matovinović, 2009.; Hallan et al., 2012.; Vaidya and Aeddula, 2020b) . In old age at risk of kidney disease, in which the factor history of the disease family, can easily develop into kidney Disease chronic (Alkerwi et al., 2017) .

System urine on the part of the nephron acts as a filter, the kidneys are disorders after the age of 40 years occur due to penurunkan function kidney. Increasing age can increase the risk of diseases such as hypertension, heart disease, and diabetes, which lead to the development of chronic kidney disease, so that the damaged kidney can not be recovered back (Kazancioğlu, 2013., Prakash and o'hare, 2009) .

Reduced muscle mass and loss of mass the kidneys due to a decrease in kidney function. Occurs in old age, found in creatinine clearance $(\mathrm{CrCi})$ and a decrease in ekresi creatinine urine. Research xenon-washout show that the kidneys decreased progressively in blood flow per mass unit of the kidney that is associated with advanced age. Epidemiological studies have shown that acceleration of the loss of kidney function related to age can be attributed with hypertension systemic, lead exposure, smoking, dyslipidemia, disease atherosclerotic or narrowing of blood vessels (Weinstein and Anderson, 2010.; Yu et al., 2012).

\section{b. Gender}

Man has the prevalence of chronic kidney disease is greater than the with women, and can attack on the male gender and women (Yu et al., 2012., Budiarto and Anggraeni., 2002). The development of chronic kidney disease is caused lack of fluids and electrolytes in the body, consumption of drugs as well as lifestyle changes, thus enhancing the development of kidney disease (Chang et al., 2016.; Savadi.; 2016) . 
Level the development of chronic kidney disease are at risk of causing death, higher obtained in male gender compared women, due to a decrease in the rate of filtration glomerular and increased levels of albuminuria, while the level of development of chronic kidney disease affected by the lifestyle factors that increase the risk of disease occurrence chronic renal (Cobo et al., 2016.; Yu et al., 2012.; Kazancioğlu, 2013).

\section{c. Hypertension}

Hypertension is an increase in blood pressure is $140 / 90 \mathrm{mmHg}$, which causes sodium retention so Renin Angiotensin Aldosterone (RAA) increase in blood pressure that affects the nervous system sympathetic and experienced damage to the kidneys (Barri, 2008.; Echder $\mathrm{T}, 2012)$. Hypertension is a major risk factor for cardiovascular disease and kidney as well as the risk to morbidity and mortality (Tedla et al., 2011.; Pirkle and Freedman, 2013).

Expert expert nephrology of the faculty of medicine, University of Indonesia Professor dr Jose Roesma explained that hypertension and the kidney closely related. Patients with hypertension most likely the kidney will be interrupted while the chronic kidney disease will aggravate the condition disease hypertension that can affect the health of the heart, due to change unhealthy lifestyle such as smoking, consumption of alcohol, and no activity (Kazancioğlu, 2013.; Damtie et al., 2018.; Alkerwi et al., 2017).

\section{d. Diabetes}

The prevalence of diabetes is increasing in Indonesia due to population growth, urbanization, and lifestyle. Diabetes is the leading cause of chronic kidney disease which can increase mortality, but not all diabetes develops into chronic kidney disease (Mihardja et al., 2018; Damtie et al., 2018). Diabetes is a chronic disease that causes complications, if prevention and treatment are not carried out, the incidence of CKD will continue to increase (Harjutsalo and Groop, 2014; Wouters, 2015).

High glucose in the blood comes from energy sources found in food. The function of insulin and glucagon hormones, namely regulating blood glucose levels that function to balance blood glucose. The pancreas will secrete insulin during food consumption so the prangkeas secretes glucagon to maintain a balanced sugar level. Diabetics are not able to produce urine, if the amount of glucose released is not appropriate then the body will lose balance and increase blood glucose (Tjahjadi, 2002 .; Alicic et al., 2017).

Complications of diabetic nephropathy are impaired renal function due to leakage of the blood filter membrane (glomerulus) and drain proteins, especially albumin from the blood, into the urine. High blood sugar levels will slowly damage the glomerulus. When the kidneys function properly, the nephron functions to maintain the condition of proteins in the body. High sugar levels will react with proteins that change cell structure and function, including glomerular basement membranes, which will cause protein leakage into the urine (Murea and Freedman, 2010; Ghaderian and Beladi-Mousavi, 2014).

\section{Research Method}

This research is a cross sectional analytic research with a retrospective approach, this research is by searching the previous data. The data used in this study are secondary data at Rumah Sakit Umum Cut Meutia (RSUCM), North Aceh Regency in 2019, which aims to analyze risk factors associated with Chronic Kidney Disease (CKD). This research was conducted at Rumah Sakit Umum Cut Meutia (RSUCM), North Aceh District from 8 to 9 June 2020. 
The population included in this study were all patients with chronic kidney disease who received treatment at the Cut Meutia General Hospital in North Aceh Regency for the period January - December 2019 as many as 640 people.

\section{Result and Discussion}

\subsection{Results}

\section{a. The Results of the Univariate Analysis}

Univariate analysis is an analysis used on one variable with the aim of knowing and identifying the characteristics of the variables:

Table 1. Frequency Distribution of Risk Factors for Chronic Kidney Disease at Rumah Sakit Umum Cut Meutia, North Aceh Regency 2019 (n=86)

\begin{tabular}{llcc}
\hline No & Age & Frequency & Percentage \\
\hline $\mathbf{1}$ & Risk low $\leq 65$ tahun & 73 & 84,9 \\
& Risk high $\geq 65$ years & 13 & 15,1 \\
\hline No & Type Sex & Frequency & Percentage \\
\hline $\mathbf{2}$ & Men & 39 & 45,3 \\
& Women & 47 & 54,7 \\
\hline No & Hypertension & Frequency & Percentage \\
\hline $\mathbf{3}$ & Hypertension & 51 & 59,3 \\
& Not Hypertension & 35 & 40,7 \\
\hline No & Diabetes & Frequency & Percentage \\
\hline $\mathbf{4}$ & Diabetes & 57 & 66,3 \\
& Not diabetes & 29 & 33,7 \\
\hline No & Disease chronic kidney & Frequency & Percentage \\
\hline $\mathbf{5}$ & There & 49 & 57,0 \\
& Not & 37 & 43,0 \\
\hline & Total & $\mathbf{8 6}$ & $\mathbf{1 0 0}$ \\
\hline & \multicolumn{2}{c}{ Source $:$ Secondary data processed June $(2020)$}
\end{tabular}

Based on table 1, total sample of 86 respondents can be concluded that the most dominant is the age category of low risk 73 respondents (84.9\%), female gender as many as 47 respondents $(54.7 \%)$, hypertension sufferers as much as 51 respondents $(59.3 \%), 57$ diabetics $(66.3 \%)$, CKD who had dialysis as many as 49 respondents $(57 \%)$.

Table 2. Frequency Distribution of Patients with Chronic Kidney Disease by Age Group in Cut Meutia General Hospital

\begin{tabular}{llll}
\hline No & Group Age & Frequency & The percentage of \\
\hline 1 & $<40$ Years & 4 & 4,7 \\
\hline 2 & $40-49$ Year & 19 & 22,0 \\
\hline 3 & $50-59$ Year & 28 & 32,6 \\
\hline 4 & $>60$ Years & 35 & 40,7 \\
\hline & Total & $\mathbf{8 6}$ & $\mathbf{1 0 0}$ \\
\hline
\end{tabular}

Based on table 2 above, it can be seen that age in patients with chronic kidney disease is dominant in the age group> 60 years, namely 35 respondents $(40.7 \%)$. 


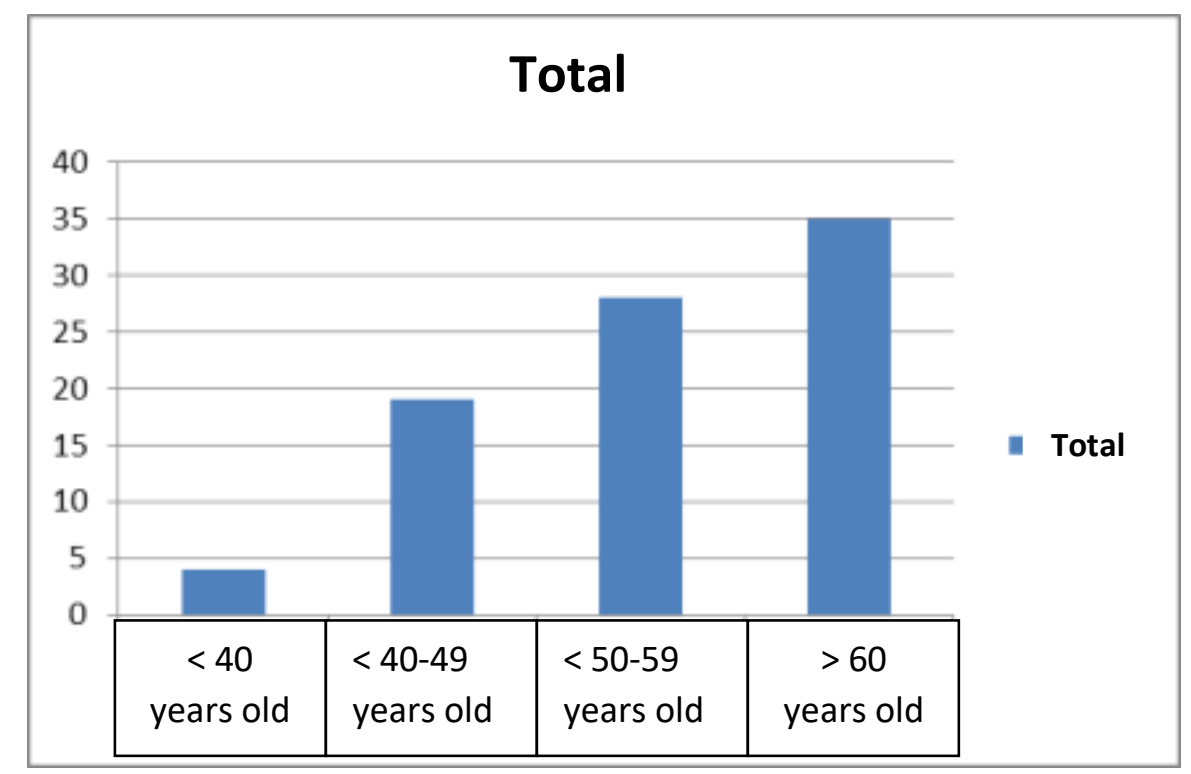

Figure 1. Chronic Kidney Disease based on the Age Group

\section{b. Bivariate Analysis Results}

Bivariate analysis is an inferential statistical method used to analyze the data of two research variables to find out there is a relationship between the two variables. Where the statistical test results are displayed in the following table:

1. Relationship between Age and Chronic Kidney Disease

Table 3. Relationship between Age and the Risk of Chronic Kidney Disease in Rumah Sakit Umum Cut Meutia, North Aceh Regency 2019 (n=86)

\begin{tabular}{|c|c|c|c|c|c|c|c|c|}
\hline \multirow{3}{*}{$\begin{array}{l}<40 \text { years } \\
\text { old }\end{array}$} & \multicolumn{4}{|c|}{ Chronic Kidney Disease } & \multirow{2}{*}{\multicolumn{2}{|c|}{ Total }} & \multirow[t]{3}{*}{ P Value } & \multirow[t]{3}{*}{ OR } \\
\hline & \multicolumn{2}{|c|}{ HD } & \multicolumn{2}{|c|}{ Non HD } & & & & \\
\hline & $\mathrm{n}$ & $\%$ & $\mathrm{n}$ & $\%$ & $\mathrm{n}$ & $\%$ & & \\
\hline Age & & & & & & & & \\
\hline $\begin{array}{l}\text { Low Risk } \\
\leq 65 \text { years old }\end{array}$ & 42 & 57,5 & 31 & 42,5 & 73 & 100 & 1 & 1,1 \\
\hline $\begin{array}{l}\text { High Risk } \\
\geq 65 \text { years old }\end{array}$ & 7 & 53,8 & 6 & 46,2 & 13 & 100 & & \\
\hline Jumlah & 49 & & 37 & & 86 & 100 & & \\
\hline
\end{tabular}

Based on table 3, the age relationship with chronic kidney disease from 86 respondents including 73 respondents in the low risk age category $\leq 65$ years by $57.5 \%$ suffering from CKD, while 13 respondents with high risk age category by 53.8\% suffer from CKD. Statistical test results obtained p-value 1 means that there is no statistical relationship between age and chronic kidney disease at the Cut Meutia General Hospital. Statistical test results obtained OR value $=1.1$ means that chronic kidney disease with a low risk age $\leq 65$ years has a 1.1 times chance of suffering from CKD compared to a low risk age $\geq 65$ years. 
2. Relationship between Gender and Chronic Kidney Disease

Table 4. Relationship between Gender and the Risk of Chronic Kidney Disease in Rumah Sakit Umum Cut Meutia, North Aceh Regency 2019 (n=86)

\begin{tabular}{|c|c|c|c|c|c|c|c|c|}
\hline \multirow[t]{3}{*}{ Gender } & \multicolumn{4}{|c|}{ Chronic Kidney Disease } & \multirow{2}{*}{\multicolumn{2}{|c|}{ Total }} & \multirow[t]{3}{*}{ P Value } & \multirow[t]{2}{*}{ P Value } \\
\hline & \multicolumn{2}{|c|}{ HD } & \multicolumn{2}{|c|}{ Non HD } & & & & \\
\hline & $\mathrm{n}$ & $\%$ & $\mathrm{n}$ & $\%$ & $\mathrm{n}$ & $\%$ & & \\
\hline Male & 20 & 51,3 & 19 & 48,7 & 39 & 100 & 0,452 & 6,5 \\
\hline Female & 29 & 61,7 & 18 & 38,3 & 47 & 100 & & \\
\hline Total & 49 & & 37 & & 86 & 100 & & \\
\hline
\end{tabular}

Source: Secondary Data Processed (2020)

Based on table, the relationship between gender and chronic kidney disease has 86 respondents including 39 respondents type of male genital amounted to $51.3 \%$ of suffer from the CKD, whereas of the 47 respondents female gender amounted to $61,7 \%$ suffer from CKD.

Based on the statistical test result obtained p-value 0,452 meaning, there is no relationship statistically between the genre and chronic kidney disease in Rumah Sakit Umum Cut Meutia. Statistical test result obtained a value of $\mathrm{OR}=$ The 6.5 which is chronic kidney disease that women have opportunities 6,5 times suffering from CKD compared with male.

3. Relationship between Hypertension and Chronic Kidney Disease

Table 5. Relationship between Hypertension and the Chronic Kidney Disease in Rumah Sakit Umum Cut Meutia, North Aceh Regency 2019 ( $\mathrm{n}=86)$

\begin{tabular}{|c|c|c|c|c|c|c|c|c|}
\hline \multirow[t]{3}{*}{ Hypertension } & \multicolumn{4}{|c|}{ Chronic Kidney Disease } & \multirow{2}{*}{\multicolumn{2}{|c|}{ Total }} & \multirow[t]{3}{*}{ P Value } & \multirow[t]{2}{*}{$\mathbf{O R}$} \\
\hline & \multicolumn{2}{|c|}{ HD } & \multicolumn{2}{|c|}{ No HD } & & & & \\
\hline & $\mathrm{n}$ & $\%$ & $\mathrm{n}$ & $\%$ & $\mathrm{n}$ & $\%$ & & \\
\hline Hypertension & 38 & 74,5 & 13 & 25,5 & 51 & 100 & 0,000 & 6,3 \\
\hline No & 11 & 31,4 & 24 & 68,6 & 35 & 100 & & \\
\hline \multicolumn{9}{|l|}{ Hypertension } \\
\hline Jumlah & 49 & & 37 & & 86 & 100 & & \\
\hline
\end{tabular}

Based on table, the relationship between hypertension and CKD has 86 respondents, 51 respondents are hypertension, 74,5\% suffer from $\mathrm{CKD}$, while 35 respondents did not hypertension and 68,6\% do not suffer from CKD. The statistical test result obtained p-value 0,000 , there is a relationship between the hypertension and chronic kidney disease at Rumah Sakit Umum Cut Meutia. The statistical test results obtained the value $\mathrm{OR}=6,3$. It means that chronic kidney disease with hypertension have opportunities 6,3 times suffering from CKD compared to those without hypertension.

4. Relationship between Diabetes and Chronic Kidney Disease

Table 6. The Relationship between Diabetes and Chronic Kidney Disease at Rumah Sakit Umum Cut Meutia, North Aceh Regency 2019 (n=86)

\begin{tabular}{|c|c|c|c|c|c|c|c|c|}
\hline \multirow[t]{3}{*}{ Diabetes } & \multicolumn{4}{|c|}{ Chronic Kidney Disease } & \multirow{2}{*}{\multicolumn{2}{|c|}{ Total }} & \multirow[t]{3}{*}{ P Value } & \multirow[t]{3}{*}{ OR } \\
\hline & \multicolumn{2}{|c|}{ HD } & \multicolumn{2}{|c|}{ No HD } & & & & \\
\hline & $\mathrm{n}$ & $\%$ & $\mathrm{n}$ & $\%$ & $\mathrm{n}$ & $\%$ & & \\
\hline Diabetes & 38 & 74,5 & 13 & 25,5 & 51 & 100 & 0,000 & 6,3 \\
\hline No Diabetes & 11 & 31,4 & 24 & 68,6 & 35 & 100 & & \\
\hline Total & 49 & & 37 & & 86 & 100 & & \\
\hline
\end{tabular}

Source: Secondary Data Processed (2020) 
Based on table 6 shows that the relationship of gender with chronic kidney disease of 86 respondents including 39 male respondents of $51.3 \%$ suffering from CKD, while of 47 female respondents of $61.7 \%$ suffer from CKD.

Statistical test results obtained a p-value of 0.452 meaning that there was no statistical relationship between gender and chronic kidney disease in Rumah Sakit Umum Cut Meutia. Statistical test results obtained OR value $=6.5$ means that chronic kidney disease with female gender has a 6.5 times chance of suffering from CKD compared to male gender.

\subsection{Discussion}

\section{a. The Relationship between Age and Chronic Kidney Disease}

The relationship between age and chronic kidney disease showed 86 respondents, 73 were in the low risk age category $\leq 65$ years old where $57.5 \%$ had chronic kidney disease with HD, while the high risk age $\geq 65$ years old were $53.8 \%$ suffering from chronic kidney disease is HD. The results of the analysis with the Chi-square test obtained a p-value of 1 , and $\mathrm{OR}=1.1$ means that there is no relationship between age and chronic kidney disease where the age of low risk has a 1.1 times chance of suffering from chronic kidney disease compared to high risk age.

Age is a risk factor for the incidence of chronic kidney disease due to a decrease in the rate of filtration in higher albuminuria found in older age and is a risk factor for the development of chronic kidney disease and is associated with a higher risk of death than young age (Prakash and O'Hare, 2009; Hallan et al., 2012., Haileamlak, 2018).

Age at risk of developing chronic kidney disease, the higher the age will affect the disorders of the excretory system thereby reducing kidney function. The kidneys experience nephron loss after the age of 40 years. Increasing age with chronic diseases is due to the risk of diseases such as hypertension, heart disease, and diabetes, which cause the kidney organs to not work so that as a result the glomerular kidney function and tubules become damaged. Kidney work is faster and can cause mild to severe complaints and can not be recovered (Nature and Hadibroto., 2007; Kazancioğlu, 2013., Prakash and O'Hare, 2009).

This study is comparable to Harahap's research (2016), the incidence of CKD at young age is the same portion as elderly patients. Where the results of this study stated that the most chronic kidney disease occurs at the young age of 46-55 years (27\%). Likewise with the results of the Hervinda study (2014), the results of the study stated that the highest chronic kidney disease was found in female sex (53\%) compared to men (47\%) and increased with age (Hervinda, S. 2014 ). The results of research conducted at the Cut Meutia General Hospital showed that the age of low risk $\leq 65$ years from 86 respondents 73 of them suffered from chronic kidney disease as much as $57.5 \%$. The results of chronic kidney disease research based on the most dominant age group were at age $>60$ years as many as 35 respondents $(40.7 \%)$.

The assumptions research in this study is kidney disease can occur in young and old age. This is inseparable from an aging lifestyle that can increase the risk of diseases such as hypertension, diabetes and heart disease that cause organs to not be done properly (Prakash and O'Hare, 2009; Yu et al., 2012; Weinstein and Anderson, 2010).

\section{b. The Relationship between Gender and Risk of Chronic Kidney Disease Chronic}

The relationship between gender and chronic kidney disease shows that of 86 respondents, 39 were male, with $51.3 \%$ suffering from chronic kidney disease with HD, while of 47 respondents with female gender, $61.7 \%$ had chronic kidney disease. there is HD. The results of the analysis using the Chi-square test obtained a p-value of 0.452 and $\mathrm{OR}=6.5$ which means there is no relationship between gender variables with chronic kidney disease 
where female sex has a 6.3 times chance of suffering from chronic kidney disease compared to men guys.

The results of this study disagree with Levey's theory (2007), explaining that sex is a variable to distinguish the incidence rate in men or women, with the incidence of chronic kidney disease twice as much found in men than women, due to men more susceptible to the occurrence of systemic diseases such as hypertension, diabetes, glomerulonephritis, polycystic kidneys, lupus and family history of kidney disease. This also contradicts what was stated by Chang (2016), who said that risk factors for the development of chronic kidney disease were more found in male than female.

The research assumption on the results of this study is that the cause of chronic kidney disease is a lifestyle that is the habit of consuming food and drinks, where male and women have almost the same consumption habits, such as consumption of coffee and energy drinks which are also consumed by women (Chang et al., 2016; Savadi .; 2016).

Hypertension is the causes and important consequences of kidney disease chronic. also evidence from various clinical trials that have demonstrated the benefits of control of blood pressure. Control the systemic blood pressure often slow down or hold back the development of nephropathy in individuals who have hypertension so as to reduce the the rate of filtration glomerular (GFR) and proteinuria sub-nephrotic.(Tedla et al., 2011.; Pirkle and Freedman, 2013) .

\section{c. The Relationship between Hypertension and Chronic Kidney Disease}

The relationship of hypertension with chronic kidney disease showed that of 86 respondents, 51 of them were hypertension patients where $74.5 \%$ had chronic kidney disease with HD, while of 35 respondents with no hypertension category, $68.6 \%$ had chronic kidney disease not HD. The results of the analysis using the Chi-square test obtained a p-value of 0,000 with an OR of 6.3 , which means there is a relationship between the variables of hypertension and chronic kidney disease where hypertension sufferers have a 6.3 times chance of suffering from chronic kidney disease compared to not hypertension.

Hypertension is an increase in blood pressure over 140/90 $\mathrm{mmHg}$, which causes sodium retention so that Renin Angiotensin Aldosterone (RAA) increases blood pressure which affects the sympathetic nervous system and kidney damage (Barri, 2008; Echder T, 2012).

Increased blood pressure causes sclerosis of blood vessels and causes damage to kidney function by activating the release of renin which changes angiotensinogen so that it causes a vasoconstriction effect that increases blood pressure, thus causing glomerular obliteration which causes a decrease in kidney function (Guyton and Hall, 2007 .; Barri, 2008) .

Hypertension contributes to the development of kidney disease as well as cardiovascular events such as myocardial infarction, heart failure, and stroke. The prevalence of hypertension increases in patients with kidney disease, and increases progressively when the glomerular filtration rate decreases. hypertension factors due to metabolic and endocrine abnormalities involving calcium and phosphorus metabolism found in chronic kidney disease (Phan et al., 2014; Pirkle and Freedman, 2013; Tedla et al., 2011).

The results of this study are in line with Hidayati (2018), showing hypertension, smoking, and supplement drinks increase the prevalence of chronic kidney disease at PKU Muhammadiyah Hospital, Yogyakarta where the prevalence of chronic kidney disease has a hypertension relationship with an $\mathrm{OR}$ value of $3.68(\mathrm{CI}=1,39-9.74 ; \mathrm{p}<0.05), 6.63(\mathrm{CI}=$ 2.53 - 17.35; $\mathrm{p}<0.05), \mathrm{OR}=23.15(\mathrm{CI}=8.73-61.41 ; \mathrm{p}<0.05)$. This also agrees with Boreleh (2019), where the results of the study showed a significant relationship between the variables of hypertension and chronic kidney disease, the value of $\mathrm{OR}=9,100(95 \% \mathrm{CI}=$ 3,315-26,584) (Hidayati T. 2018 .; Baroleh, 2019). 
Hypertension is an important cause and consequence of chronic kidney disease. also evidence from various clinical trials that have shown the benefits of blood pressure control. Controlling systemic blood pressure often slows or stifles the development of nephropathy in hypertensive individuals so as to reduce the rate of glomerular filtration (GFR) and subnephrotic proteinuria. (Tedla et al., 2011; Pirkle and Freedman, 2013).

\section{d. The Relationship between Diabates and Chronic Kidney Disease}

The relationship of diabetes with chronic kidney disease showed that of 86 respondents, 57 were diabetic patients in which $73.7 \%$ had chronic kidney disease with HD, while of the 29 respondents with the category of no diabetes, as many as $75.9 \%$ had chronic non-HD kidney disease. The results of the analysis with the Chi-square test obtained a p-value of 0,000 , and $\mathrm{OR}=8.8$, which means that there is a relationship between diabetes variables and chronic kidney disease where diabetics have 8.8 times the chance of suffering from chronic kidney disease than those without diabetes.

\section{Conclusion}

There is no relationship between demographic statuses at age with the risk of chronic kidney disease where $\mathrm{p}$-value is 1 . There is no relationship between demographic status in sex with risk of chronic kidney disease where $p$ value is 0.452 . There is a relationship between comorbidities in hypertension and the risk of chronic kidney disease where the $p$ value is 0,000 . There is a relationship between comorbid diseases in diabetes with the risk of chronic kidney disease where the $\mathrm{p}$ value is 0,000 .

\section{References}

Adiwijaya, S., Aritonang, D. V. A., and Mashud, M. Empowerment Pattern for Thalasemi Patients in Dr. Soetomo Hospital Surabaya (Study of the Association of Parents with Thalassemia Indonesia, Surabaya). Budapest International Research and Critics Institute-Journal (BIRCI-Journal) (1): 289-298.

Alam, S dan Hadibroto I., 2007. Gagal Ginjal. PT Gramedia Pustaka Utama., Jakarta

Alicic, R.Z., Rooney, M.T., Tuttle, K.R., 2017. Diabetic Kidney Disease. Clin J Am Soc Nephrol 12, 2032-2045. https://doi.org/10.2215/CJN.11491116

Alkerwi, A., Sauvageot, N., El Bahi, I., Delagardelle, C., Beissel, J., Noppe, S., Roderick, P.J., Mindell, J.S., Stranges, S., 2017. Prevalence and related risk factors of chronic kidney disease among adults in Luxembourg: evidence from the observation of cardiovascular risk factors (ORISCAV-LUX) study. BMC Nephrol 18. https://doi.org/10.1186/s12882-017-0772-6

Anand, S., Thomas, B., Remuzzi, G., Riella, M., Nahas, M.E., Naicker, S., Dirks, J., 2017. Kidney Disease, in: Prabhakaran, D., Anand, S., Gaziano, T.A., Mbanya, J.-C., Wu, Y., Nugent, R. (Eds.), Cardiovascular, Respiratory, and Related Disorders. The International Bank for Reconstruction and Development/The World Bank, Washington (DC).

Arifa. S. I. 2017. Factors Associated with Chronic Kidney Disease Incidence among Patients with Hypertension in Indonesia. Jurnal Mkmi, Vol. 13 No. 4)

Barri, Y. M. 2008. Hypertension and kidney disease: a deadly connection. Curr. Hypertens. Rep. 10, 39-45. https://doi.org/10.1007/s11906-008-0009-y 
Baroleh. M. J. 2019. Faktor-Faktor Yang Berhubungan Dengan Penyakit Ginjal Kronis Pada Pasien Di Instalasi Rawat Jalan Rumah Sakit Umum Pancaran Kasih Manado. Jurnal Kesehatan Masyarakat. Vol.8. No.7 (2019) https://ejournal.unsrat.ac.id/index.php/kesmas/article/view/27233)

Budiarto, Eko dan Dewi Anggraeni.2002. Epidemiologi. Jakarta :EGC

Chang, P.-Y., Chien, L.-N., Lin, Y.-F., Wu, M.-S., Chiu, W.-T., Chiou, H.-Y., 2016. Risk factors of gender for renal progression in patients with early chronic kidney disease. Medicine (Baltimore) 95. https://doi.org/10.1097/MD.0000000000004203

Cobo, G., Hecking, M., Port, F.K., Exner, I., Lindholm, B., Stenvinkel, P., Carrero, J.J., 2016. Sex and gender differences in chronic kidney disease: progression to end-stage renal disease and haemodialysis. Clin Sci (Lond) 130, 1147-1163. https://doi.org/10.1042/CS20160047

Colvy, Jack. 2010. Tips Cerdas Mengenali dan Mencegah Gagal Ginjal. Yogyakarta: DAFA Publishing.

Crews, D.C., Bello, A.K., Saadi, G., 2019. 2019 World Kidney Day Editorial - burden, access, and disparities in kidney disease. J Bras Nefrol 41, 1-09. https://doi.org/10.1590/2175-8239-JBN-2018-0224

Dinas Kesehatan Aceh (Dinkes)., 2018. Profil Kesehatan Aceh Tahun 2017 Dinas Kesehatan Aceh. https://dinkes.acehprov.go.id

Echder T, Schriner RW. (2012). Cardiovascular Abnormalites in Autosomal Dominant Polistic Kidney Disease. Nat Rev Nephrol.

Fraser, S.D., Blakeman, T., 2016. Chronic kidney disease: identification and management in primary care. Pragmat Obs Res 7, 21-32. https://doi.org/10.2147/POR.S97310

Ghaderian, S.B., Beladi-Mousavi, S.S., 2014. The role of diabetes mellitus and hypertension in chronic kidney disease. J Renal Inj Prev 3, 109-110. https://doi.org/10.12861/jrip.2014.31

Guyton A.C. and J.E. Hall 2007. Buku Ajar Fisiologi Kedokteran. Edisi 9. Jakarta: EGC.

Haileamlak, A., 2018. Chronic Kidney Disease is on the Rise. Ethiop J Health Sci 28, 681682. https://doi.org/10.4314/ejhs.v28i6.1

Hallan, S.I., Matsushita, K., Sang, Y., Mahmoodi, B.K., Black, C., Ishani, A., Kleefstra, N., Naimark, D., Roderick, P., Tonelli, M., Wetzels, J.F.M., Astor, B.C., Gansevoort, R.T., Levin, A., Wen, C.-P., Coresh, J., 2012. Age and the Association of Kidney Measures with Mortality and End-Stage Renal Disease. JAMA 308, 2349-2360. https://doi.org/10.1001/jama.2012.16817

Harjutsalo, V., Groop, P.-H., 2014. Epidemiology and Risk Factors for Diabetic Kidney Disease. Advances in Chronic Kidney Disease, Diabetic Kidney Disease 21, 260-266. https://doi.org/10.1053/j.ackd.2014.03.009

Haslinur, S., Saputra, I., Syahrizal, D., Bakhtiar, and Usman, S. 2020. Analysis of Differences between INA CBG's Rates and Hospital Real Rates in Hemophilia Patients at RSUD Zainoel Abidin Banda Aceh. Budapest International Research and Critics Institute-Journal (BIRCI-Journal) (3): 1758-1763.

Haynes, R., Staplin, N., Emberson, J., G. Herrington, W., Tomson, C., Agodoa, L., Tesar, V., Levin, A., Lewis, D., Reith, C., Baigent, C., Landray, M.J., 2014. Evaluating the Contribution of the Cause of Kidney Disease to Prognosis in CKD: Results from the Study of Heart and Renal Protection (SHARP). Am J Kidney Dis 64, 40-48. https://doi.org/10.1053/j.ajkd.2013.12.013

Hervinda, S. 2014. Prevalensi dan Faktor Risiko Penyakit Ginjal Kronik di RSUP Dr. Mohammad Hoesin Palembang Tahun 2014. MKS, Th. 46, No. 4, Oktober 2014). 
Phan, O., Burnier, M., Wuerzner, G., 2014. Hypertension in Chronic Kidney Disease - Role of Arterial Calcification and Impact on Treatment. Eur Cardiol 9, 115-119. https://doi.org/10.15420/ecr.2014.9.2.115

Pirkle, J.L., Freedman, B.I., 2013. Hypertension and Chronic Kidney Disease: Controversies in Pathogenesis and Treatment. Minerva Urol Nefrol 65, 37-50.

Savadi, H., Khaki, M., Javnbakht, M., Pourrafiee, H., 2016. The Impact of Hemodialysis on Sexual Function in Male Patients using the International Index of Erectile Function Questionnaire (IIEF). Electronic Physician 8, 2371. https://doi.org/10.19082/2371

Sharma, M., Doley, P., Das, H., 2018. Etiological profile of chronic kidney disease: A singlecenter retrospective hospital-based study. Saudi J Kidney Dis Transpl 29, 409. https://doi.org/10.4103/1319-2442.229297

Webster, A.C., Nagler, E.V., Morton, R.L., Masson, P., 2017. Chronic Kidney Disease. Lancet 389, 1238-1252. https://doi.org/10.1016/S0140-6736(16)32064-5

WHO, 2018. Non Communicable Diseases [WWW Document]. https://www.who.int/news-room/fact-sheets/detail/noncommunicable-diseases (accessed 11.27.19).

WHO. 2019 The Global Burden of Kidney Disease and the Sustainable Development Goals [Internet], n.d. . WHO. https://doi.org/10.2471/BLT.17.206441

Wilson, L.M. Gagal Ginjal Kronik. Dalam: Price, S.A. \& L.M. Wilson., 2005. Patofisiologi Konsep Klinis Proses-Proses Penyakit. Volume 2. Edisi 6. EGC;Jakarta.

Wouters, O.J., O’Donoghue, D.J., Ritchie, J., Kanavos, P.G., Narva, A.S., 2015. Early chronic kidney disease: diagnosis, management and models of care. Nat Rev Nephrol 11, 491-502. https://doi.org/10.1038/nrneph.2015.85

Yu, M.K., Lyles, C.R., Bent-Shaw, L.A., Young, B.A., Authors, the P., 2012. Risk factor, age and sex differences in chronic kidney disease prevalence in a diabetic cohort: The Pathways Study. American Journal of Nephrology 36, 245.

https://doi.org/10.1159/00034Siagian, S. 2014. Manajemen Sumber Daya Manusia [Internet]. Belbuk.com2014]; Available from: https://www.belbuk.com/manajemensumber-daya-manusia-p-113.html

Sugiyono. (2016). Metode Penelitian Kuantitatif, Kualitatif dan R\&D.

Thabrany, H, et al. (2011). Health Insurance in Indonesia: Current Status and the Plan for National Health Insurance. SEARO Regional Overview in South-East Asia (online) http://www.searo.who.int/LinkFiles/Social_Health_Insurance_an3.pdf.

Wahyuni, N. (2020). The Relationship between Social Supports with Nursing Employee Attachment at Dr. R.M. Djoelham Hospital Binjai. Budapest International Research and Critics Institute-Journal (BIRCI-Journal). P. 816-828.

www.rsudza.acehprov.go.id. Profil Rumah Sakit Umum Daerah dr. Zainoel Abidin Banda Aceh. 2018. available from: https://www.ncbi.nlm.nih.gov/pmc/articles/PMC5371367/

Zafar, A, et al.(2005). Implementing Casemix System in Hospital UKM. Malaysian Journal of Public Health Medicine, 136-140. 